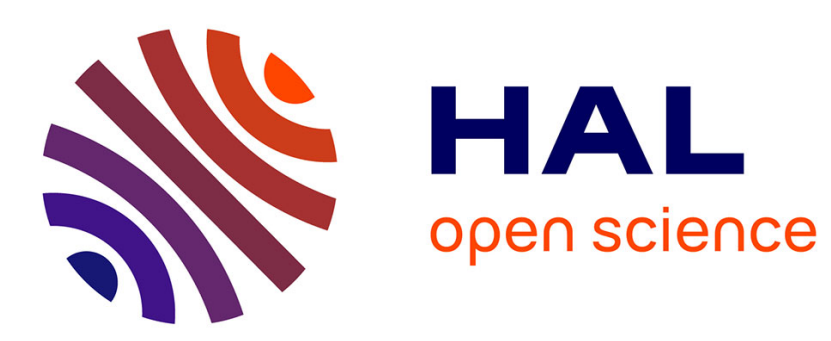

\title{
Expeditious Synthesis of C -Glycosyl Barbiturate Ligands of Bacterial Lectins: From Monomer Design to Glycoclusters and Glycopolymers
}

François Portier, Anne Imberty, Sami Halila

\section{- To cite this version:}

François Portier, Anne Imberty, Sami Halila. Expeditious Synthesis of C -Glycosyl Barbiturate Ligands of Bacterial Lectins: From Monomer Design to Glycoclusters and Glycopolymers. Bioconjugate Chemistry, 2019, 30 (3), pp.647-656. 10.1021/acs.bioconjchem.8b00847 . hal-02322076

\section{HAL Id: hal-02322076 \\ https://hal.science/hal-02322076}

Submitted on 4 Aug 2020

HAL is a multi-disciplinary open access archive for the deposit and dissemination of scientific research documents, whether they are published or not. The documents may come from teaching and research institutions in France or abroad, or from public or private research centers.
L'archive ouverte pluridisciplinaire HAL, est destinée au dépôt et à la diffusion de documents scientifiques de niveau recherche, publiés ou non, émanant des établissements d'enseignement et de recherche français ou étrangers, des laboratoires publics ou privés. 


\title{
EXPEDITIOUS SYNTHESIS OF C-GLYCOSYL BARBITURATE LIGANDS OF BACTERIAL LECTINS: FROM MONOMER DESIGN TO GLYCOCLUSTERS AND GLYCOPOLYMERS
}

\author{
François Portier, Anne Imberty and Sami Halila*
}

Univ. Grenoble Alpes, CNRS, CERMAV, 38000 Grenoble, France.

E-mail: sami.halila@cermav.cnrs.fr; Fax: +33 4765472 03; Tel : +33 476037666

\begin{abstract}
The approach developed here offers a straightforward and efficient access to $\beta$-C-glycosyl barbiturates ligands, spanning from glycomimetics to multivalent $C$-neoglycoconjugates, with the aim of deciphering structural parameters impacting the binding to pathogenic lectins. We reinvestigated the Knoevenagel condensation of barbituratic acid on protecting-group free carbohydrates and successfully designed sodium and 5,5-disubstituted $\mathrm{N}, \mathrm{N}$-dimethyl barbiturate forms of D-galactose, Lfucose, melibiose, 2'-fucosyllactose, maltose and evaluated their binding affinity by isothermal titration calorimetry with LecA (galactose-binding lectin) and LecB (fucose-binding lectin) from Pseudomonas aeruginosa and RSL (fucose-binding lectin) from Ralstonia solanacearum. The barbiturate ring was shown detrimental for binding to LecA ( $K_{D}$ in $\mathrm{mM}$ range) and even more to LecB (non-interaction) while RSL is much more tolerant especially in presence of an aromatic group ( $K_{D}$ in $\mu \mathrm{M}$ range). However, distancing the barbiturate ring from the recognition carbohydrate residue by using oligosaccharides increased affinity up to low micromolar range. Extension of our convenient synthetic approach led in two-steps to melibiose-based $C$-glycosyl barbiturates clusters and $C$-glycosyl barbiturate glycopolymers exhibiting a dramatic enhancement of binding avidity for LecA.
\end{abstract}

\section{INTRODUCTION}

It is now well established that carbohydrates and glycoconjugates mediate important biological processes, such as cell-cell communication and pathogen infection, through recognition events with a wide range of carbohydrate-binding biomolecules (proteins, carbohydrates and nucleic acids). ${ }^{1}$ As a result, considerable progress has been made in method development of carbohydrate-based diagnostic and/or therapeutic agents. For instance, the design of glycomimetics of higher affinity was developed as synthetic ligands to compete with carbohydrate-binding receptors present on pathogenic micro-organisms (bacteria, viruses). ${ }^{2,3}$ The shortest access to glycomimetics or (neo)glycoconjugates requires chemoselective ligations to the anomeric position of carbohydrates which display an aldehyde function under its opening form. ${ }^{4,5}$ In carbohydrate chemistry, the aldehydecondensation reaction is traditionally performed by amination with primary amines or with more reactive $\alpha$-nucleophiles such as oxyamine or hydrazine derivatives. These last condensation reactions were preferred because of the efficiency, chemo- and stereo-selectivity and tolerance to various solvent including water. Accordingly, we have exploited the modified Kochetkov amination ${ }^{6}$ or reductive amination ${ }^{7}$ to prepare clickable neoglycoconjugates useful for the preparation of selfassembled glyco-nanostructures. ${ }^{8}$ Interestingly, the Knoevenagel condensation using $\beta$-diketones is another very convenient method that leads to $\beta-C$-glycosides in one step directly from unprotected sugar. ${ }^{9}$ However, it has been less developed in spite of its chemical and enzymatic stability and ring integrity of the terminal reducing sugar. ${ }^{10,11}$ The major breakthrough in Knoevenagel condensation with unprotected carbohydrates has been achieved first when Galbis-Perez et al. ${ }^{12}$ reported, in the mid-1980s, the direct reaction in neutral aqueous media with barbituric acids, a cyclic $\beta$-diketone, resulting in $\beta-C$-glycosyl barbiturates. Later, Lubineau et al. ${ }^{13}$ demonstrated the efficient use of acetylacetone, a non-cyclic $\beta$-diketone, for obtention of mostly $\beta$-C-glycosidic ketones. ${ }^{14}$ More specifically, the condensation of commercially available barbituric acids with unprotected sugars have 
been successfully applied on monosaccharides (hexoses and pentoses) ${ }^{15}$ and, more recently on disaccharides ${ }^{16}$ to give anionic $\beta-C$-glycosyl barbiturates where the negative charge is delocalized among the C-4, C-5 and C- 6 carbons of the barbituric ring. Finally, Clarkson et al. benefited from the negative charge to react with various halogenated compounds in order to obtain polymerizable monomers ${ }^{17,18}$ or $C$-glycosyl lipids. ${ }^{16}$

In the light of the convenient and straightforward access to neoglycoconjugates mediated by Knoevenagel condensation with barbituric acids, there is a significant need to gain insight into the determinant structural parameters of $\beta$ - $C$-glycosyl barbiturates interacting with lectins from opportunistic pathogens such as LecA (galactose-binding lectin) and LecB (fucose-binding lectin) from Pseudomonas aeruginos ${ }^{19}$ and RSL (fucose-binding lectin) from Ralstonia solanacearum. ${ }^{20}$ These lectins are involved in bacterial adhesion to host cells. Specifically, P. aeruginosa is an opportunistic pathogen implicated in a large number of opportunistic infections in immunocompromised patients and lethal lung infections in cystic fibrosis patients. $R$. solanacearum is a widely distributed plant pathogen of major economic importance since it leads to lethal wilt in many agricultural crops. Therefore, inhibition of bacterial adhesion to host cells by synthesizing glycomimetics with high and selective affinities for targeted lectins is a promising approach for the development of preventive or therapeutic anti-infectives. ${ }^{21,22}$ For such purpose, we designed a series of specific $\beta$ - $C$-glycosyl barbiturates ligands with excellent yields. Next, we established a straightforward and convenient synthetic route to prepare and study the multivalent interactions of a $\mathrm{C}$-glycosyl barbiturates cluster and $C$-glycosyl barbiturate glycopolymers with LecA.

\section{RESULTS AND DISCUSSION}

\section{Synthesis of C-glycosyl barbiturates}

The main objective of this work was to evaluate the impact of the structural characteristics of the barbiturate ring linked to carbohydrates on the binding affinities with corresponding lectins. For such purpose, we decided to analyze multiple parameters such as the influence of the negative charge localized along the barbiturate ring, the removal of the charge by reacting it with methyl iodide or benzyl bromide and finally the distance between the charged barbiturate and the recognition carbohydrate module by using oligosaccharides. Thus, a variety of $\beta$ - $C$-glycosyl barbiturates were synthesized by Knoevenagel condensation using commercially available $N, N$-dimethylbarbituric acid and protecting-group free carbohydrates in hot water $\left(80^{\circ} \mathrm{C}\right.$ ) at neutral $\mathrm{pH}$ (Scheme 1). Since LecA is a galactose-binding lectin and LecB and RSL are fucose-binding lectins, we selected galactose-based ligands such as D-galactose (entries 1-3; Table 1) and melibiose (entry 7; Table 1) and fucose-based ligands such as L-fucose (entries 4-6; Table 1) and 2'-fucosyllactose (entry 8; Table 1) as starting material, respectively. A glucose-based ligand, i.e maltose (entry 9; Table 1), was synthesized as negative control for probing nonspecific interactions with targeted lectins.
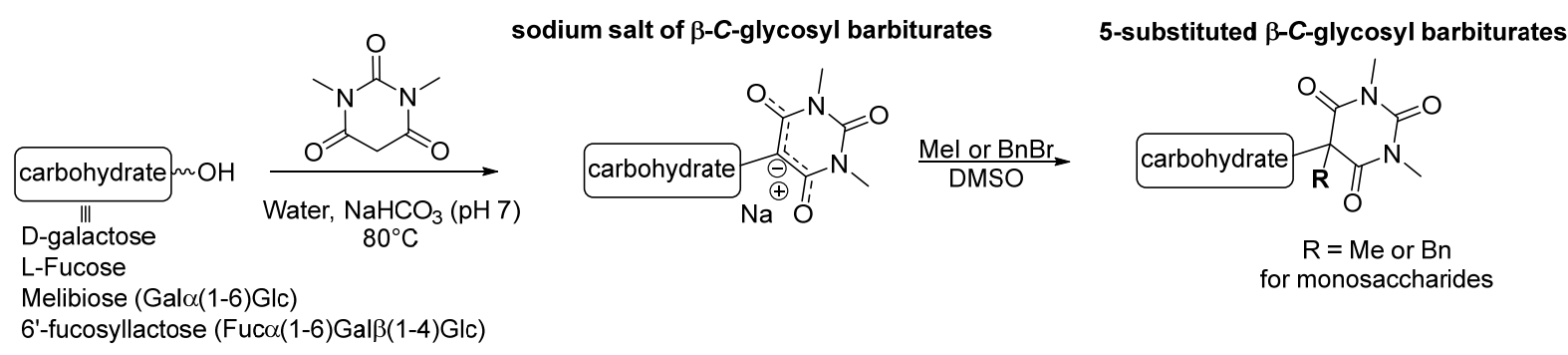

Scheme 1 Synthesis of sodium salt and 5-substituted $\beta$ - $C$-glycosyl barbiturates 
The Knoevenagel condensation was remarkably efficient (Table 1 ) and led exclusively to $\beta$-C-glycosyl barbiturates (1-5) where the $\beta$-configuration and the pyran ring were confirmed by ${ }^{1} \mathrm{H}$ NMR with a strong coupling constant of the anomeric proton $\left(J_{1,2}=10 \mathrm{~Hz}\right)$ (Figures S1, S15, S19, S35 and S40; SI). In most situations, quantitative transformations were observed by T.L.C. and purification were performed with an automatic flash chromatography system affording the product in high purity and excellent isolated yields (70-100\%).

Table 1 Structures of $\beta$ - $C$-glycosyl barbiturate derivatives

\begin{tabular}{|c|c|c|c|}
\hline Entry & Carbohydrate & $\begin{array}{c}\beta \text {-C-glycosyl barbiturate } \\
\text { (Yield \%) }\end{array}$ & $\begin{array}{c}\text { 5-substituted derivatives } \\
\text { (Yield \%) }\end{array}$ \\
\hline 1 & D-Galactose & $1(95 \%)$ & \\
\hline 2 & & & $1 \mathrm{a}(70 \%)$ \\
\hline 3 & & & 1b (90\%) \\
\hline 4 & L-Fucose & 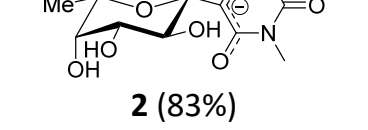 & \\
\hline 5 & & & $\begin{array}{c}\mathrm{HO} \\
2 a(90 \%)\end{array}$ \\
\hline 6 & & & $\overbrace{\mathbf{O H}}$ \\
\hline 7 & Melibiose & 3 (89\%) & \\
\hline 8 & 2'-Fucosyllactose & $4(88 \%)$ & \\
\hline
\end{tabular}




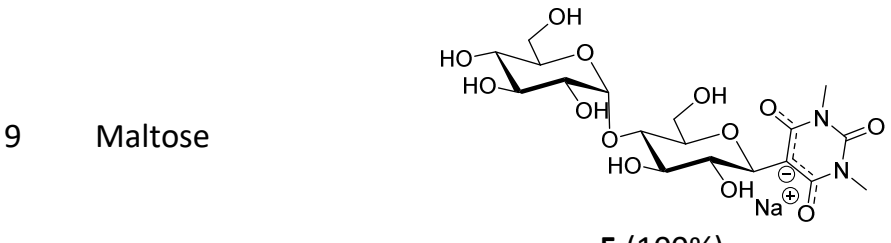

$5(100 \%)$

The sodium salts of 1,3-dimethyl-( $\beta$-C-glycopyranosyl)barbituric acid $\mathbf{1}$ and $\mathbf{2}$ were subsequently alkylated with methyl iodide and benzyl bromide in DMSO to afford $\mathbf{1 a}$ and $\mathbf{1 b}$, respectively, for Dgalactose and $\mathbf{2 a}$ and $\mathbf{2} \mathbf{b}$, respectively, for L-fucose. The methyl group was selected because of its limited steric hindrance and the benzyl group because of the potential favorable $\pi$-stacking interactions with the lectin active site. The ${ }^{13} \mathrm{C}$ NMR chemical shift for $\mathrm{C}-5$ of the barbiturate ring (ca. 55-64 ppm) confirmed the formation of 5,5-disubstituted barbiturates (Figure S5, S11, S25, S30 and S47; SI), as opposed to a value of ca. 87 ppm for 5-monosubstituted barbiturates (Figure S2, S16, S20, S36 and S41; SI) where it would form part of an enolic system. ${ }^{15}$

\section{Carbohydrate-Lectin recognition studies}

In order to assess the structural requirements for efficient binding of monovalent $C$ glycosylbarbiturates to specific lectins (1, 1a, $\mathbf{1 b}$ and $\mathbf{3}$ for LecA and $\mathbf{2}, \mathbf{2} \mathbf{a}, \mathbf{2} \mathbf{b}$ and $\mathbf{4}$ for LecB and RSL), determination of affinity constant and thermodynamic contributions were performed using titration microcalorimetry (Table 2). (Figures S53-S69; SI)

Table 2 Isothermal titration microcalorimetry data for monovalent $\beta-C$-glycosylbarbiturate derivatives binding to bacterial lectins LecA, LecB and RSL. Standard deviation is calculated over 2 or 3 experiments for the three fitted parameters.

\begin{tabular}{|c|c|c|c|c|c|c|}
\hline Lectin & Ligand & $n^{a}$ & $-\Delta H\left[\mathrm{~kJ} \mathrm{~mol}^{-1}\right]$ & $\mathrm{T} \Delta S\left[\mathrm{~kJ} \mathrm{\textrm {mol } ^ { - 1 } ]}\right.$ & $-\Delta G\left[\mathrm{~kJ} \mathrm{~mol}^{-1}\right]$ & $K_{\mathrm{D}}[\mu \mathrm{M}]$ \\
\hline \multirow{7}{*}{ LecA } & $\beta$-D-GalMe & $1^{b}$ & 19.0 & 5.3 & 24.3 & 55.7 \\
\hline & Melibiose $^{d}$ & $1^{b}$ & 35.9 & -10.9 & 25.0 & 38.8 \\
\hline & $1 \beta$-D-GalBarb & $0.8^{\mathrm{b}}$ & $5.50 \pm 0.36$ & 7.2 & 12.7 & $5900 \pm 800$ \\
\hline & 1a $\beta$-D-GalBarbMe & $0.8^{\mathrm{b}}$ & $17.2 \pm 0.1$ & -5.4 & 11.8 & $8623 \pm 149$ \\
\hline & 1b $\beta$-D-GalBarbBn & $0.8^{b}$ & $22.8 \pm 0.1$ & -7.9 & 14.9 & $2482 \pm 31$ \\
\hline & 3 MeliBarb & $0.92 \pm 0.04$ & $29.5 \pm 0.4$ & -5.7 & 23.8 & $66.3 \pm 2.6$ \\
\hline & 6 MeliBarb2 & $0.41 \pm 0.03$ & $55 \pm 2.0$ & $-18.9 \pm 2.1$ & 36.1 & $0.48 \pm 0.001$ \\
\hline \multirow{6}{*}{ LecB } & $\alpha-L-F u c M e^{e}$ & 0.77 & 41.3 & -4.9 & 36.4 & 0.43 \\
\hline & $2^{\prime}$-Fucosyllactose $e^{f}$ & $0.73 \pm 0.02$ & $41.1 \pm 0.1$ & $-6.0 \pm 0.2$ & 35.1 & $0.70 \pm 0.03$ \\
\hline & $2 \beta$-L-FucBarb & & & & & $-f^{f}-x-b e$ \\
\hline & 2a $\beta$-L-FucBarbMe & & & & & - \\
\hline & 2b $\beta$-L-FucBarbBn & & & & & - \\
\hline & $422^{\prime}$-FucLacBarb & $0.94 \pm 0.01$ & $32.5 \pm 0.1$ & 1.4 & 33.9 & $1.13 \pm 0.12$ \\
\hline \multirow{6}{*}{ RSL } & $\alpha-L-F u c M e^{g}$ & 1.98 & $42.1 \pm 1.3$ & -7.1 & 35.0 & $0.73 \pm 0.03$ \\
\hline & 2'-Fucosyllactose & $1.66 \pm 0.02$ & $51.4 \pm 0.4$ & -17.5 & 33.9 & $1.17 \pm 0.08$ \\
\hline & $2 \beta$-L-FucBarb & $1.04 \pm 0.03$ & $25.6 \pm 0.4$ & -4.5 & 21.1 & $197 \pm 13$ \\
\hline & 2a $\beta$-L-FucBarbMe & $0.77 \pm 0.02$ & $37.0 \pm 1.5$ & -16.4 & 20.6 & $252 \pm 31$ \\
\hline & $2 b \quad \beta$-L-FucBarbBn & $0.88 \pm 0.02$ & $24.9 \pm 1.5$ & 4.3 & 29.2 & $7.6 \pm 1.4$ \\
\hline & 4 2'-FucLacBarb & $1.66 \pm 0.02$ & $31.1 \pm 1.1$ & -1.9 & 29.2 & $11.8 \pm 0.5$ \\
\hline
\end{tabular}

${ }^{a}$ Stoichiometry, $n=$ number of occupied lectin binding site per ligand. ${ }^{b}$. Value fixed during the fitting procedure ${ }^{\mathrm{c}}$ Data from the literature. ${ }^{23 \mathrm{~d}}$ Data from the literature. ${ }^{24 \mathrm{e}}$ Data from the literature. ${ }^{25 \mathrm{f}}$ The $\beta$-C-fucosylbarbiturate derivatives did not show any measurable affinity in ITC (Figures S59-S61; SI). ${ }^{g}$ Data from the literature. ${ }^{20}$

From the ITC data presented in the Table 2, comparison can be made between barbiturate derivatives and methyl derivatives on monosaccharides. The barbiturate ring whether under its anionic or neutral 
(methylated or benzylated) form is detrimental for the binding to Pseudomonas lectins LecA and LecB, ( $K_{\mathrm{D}}$ in millimolar range for LecA, no interaction with LecB). RSL is less affected with a $K_{\mathrm{D}}$ around 200 $\mu \mathrm{M}$, still losing two order of magnitude when compared to methylated fucose.

In order to rationalize the observed effect of barbiturate substitution on monosaccharide affinity, compounds 1 and $\mathbf{2}$ have been manually docked in the binding sites of corresponding lectins, in agreement with known location of glycan ligand (Figure 1). Compound $\mathbf{2}$ conformations was taken from crystal structure of 5- $\beta$-D-galactopyranosyl-1,3-dimethylbarbituric acid. ${ }^{26}$ The structure of compound $\mathbf{2}$ was built from compound $\mathbf{1}$ by substituting the D-galactose ring by a L-fucose one.
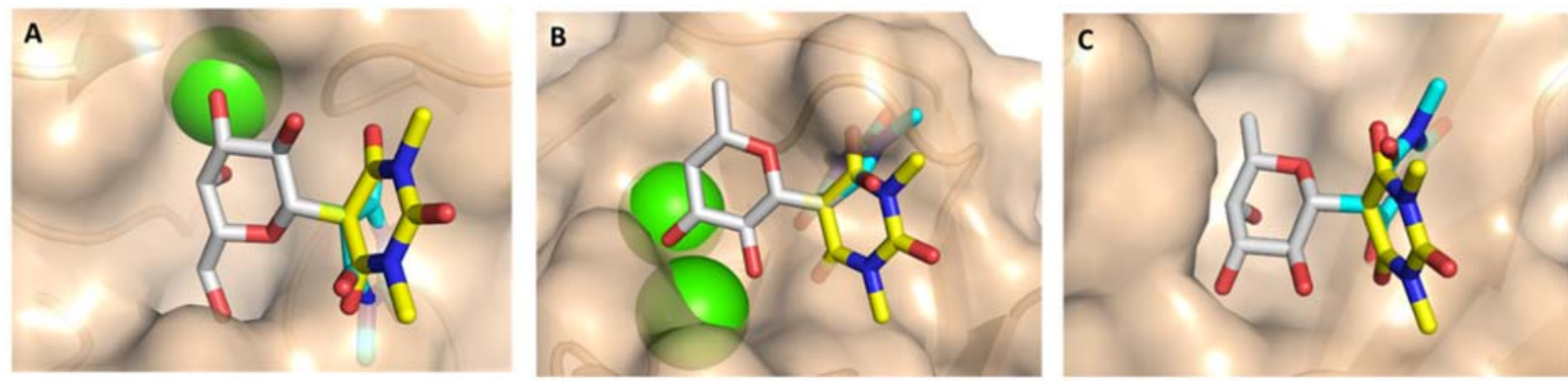

Figure 1. Manual docking of compound $\mathbf{1}$ and $\mathbf{2}$ in lectins binding sites, with two conformations for the barbiturate ring, indicated in cyan and yellow. The protein surface is colored in beige and calcium ions are represented as green spheres. A: LecA (Pdb code 1OKO) complex with compound 1 . B and C: LecB (code 1GZT) and RSL (code 1BT9) complexes with compound $\mathbf{2}$.

Two different conformations were generated for exploring the flexibility of the barbiturate around the carbon-carbon aglycone bound. In all cases, the conformation observed in the crystal structure ${ }^{26}$ generates steric conflict with the protein surface, although in a limited way for the RSL complex that presents a flat area close to the fucose binding site. Testing an alternate orientation of the barbiturate could relieve the steric conflicts for LecA and RSL, but not for LecB. This structural analysis is in agreement with the binding data, confirming that LecB cannot accommodate a barbiturate ring on the fucose, while LecA, and in a larger extension RSL can bind to it, albeit with some conformational rearrangement.

When a benzyl group is attached to the barbiturate (compound $\mathbf{1 b}$ ) the affinity was significantly enhanced for LecA. Indeed, it was already reported that phenyl aglycon in galactoside have stronger affinity ${ }^{23}$ and structural data demonstrated the role of an intermolecular $\mathrm{CH}-\pi \mathrm{T}$-shape interaction between $\mathrm{C}(\varepsilon 1)-\mathrm{H}$ of residue His50 in LecA and the aromatic ring of the galactoside aglycone. ${ }^{27}$ Similarly, a strong binding is obtained for $\mathbf{2 b}\left(K_{\mathrm{D}}\right.$ of $\left.7.3 \mu \mathrm{M}\right)$ with RSL, representing a 28 -fold increase compared to $\mathbf{2}$ and $\mathbf{2 a}$. Interestingly, $\mathbf{2} \mathbf{b}$ appeared to be an excellent discriminating ligand, strongly preferring the fucophilic lectin RSL rather than LecB. Such fine specificity with a bulky aglycon derivative was previously observed with a conformationally constrained fucoside. ${ }^{28}$

In order to avoid the streric hindrance, the barbiturate ring was distanced from the terminal residue $\alpha$-D-galactosyl or $\alpha$-L-fucosyl by using oligosaccharide spacers. Such strategy drastically increased the binding affinity for all studied lectins $\left(K_{\mathrm{D}} 3 / \mathrm{Lec} A=66.2 \mu \mathrm{M}, K_{\mathrm{D}} 4 / \mathrm{LecB}=1.3 \mu \mathrm{M}, K_{\mathrm{D}} 4 / \mathrm{RSL}=11.8 \mu \mathrm{M}\right)$; iv) with affinity in the same range as the previously published data for corresponding free oligosaccharides (Table 2).

The analysis of the thermodynamic contributions demonstrated some unusual effect of the barbiturate ring. All lectin-ligand interactions in Table 2 are enthalpy-driven as usually observed for carbohydratelectin interactions ${ }^{29}$ with a strong negative enthalpy due to occurrence of many hydrogen bonds. 
However, in presence of the barbiturate, the entropy term is not always unfavorable, demonstrating that limitation of the conformational flexibility is a strategy of interest for enhancing affinity. Finally, no interactions were observed between the three lectins and $\beta-C$-maltosyl barbiturate derivative $\mathbf{5}$, thereby confirming the absence of nonspecific interactions.

\section{Synthesis of glycoclusters and glycopolymers with binding assays}

Capitalizing on structural parameters of $\beta$-C-glycosyl barbiturates promoting the interactions with studied lectins, we envisioned increasing the potency of our glycomimetics through a rapid and original access to multivalent glycoclusters and glycopolymers according to a two-step procedure. We developed the strategy with $\beta$ - $C$-melibiosyl barbiturate derivative which was demonstrated in our study as a potent inhibitor of LecA. As previously, the first step consisted in synthesizing the 1,3dimethyl-( $\beta$ - $C$-melibiosyl)barbituric acid sodium salt $\mathbf{3}$ and the second step involved the grafting onto various halogenated benzyl scaffolds via an alkylation of the barbiturate ring (Scheme 2). We were delighted to find that our two-step process proceeded well with commercially available 4,4'bis(bromomethyl) -1,1'-biphenyl and poly(4-iodomethylstyrene).

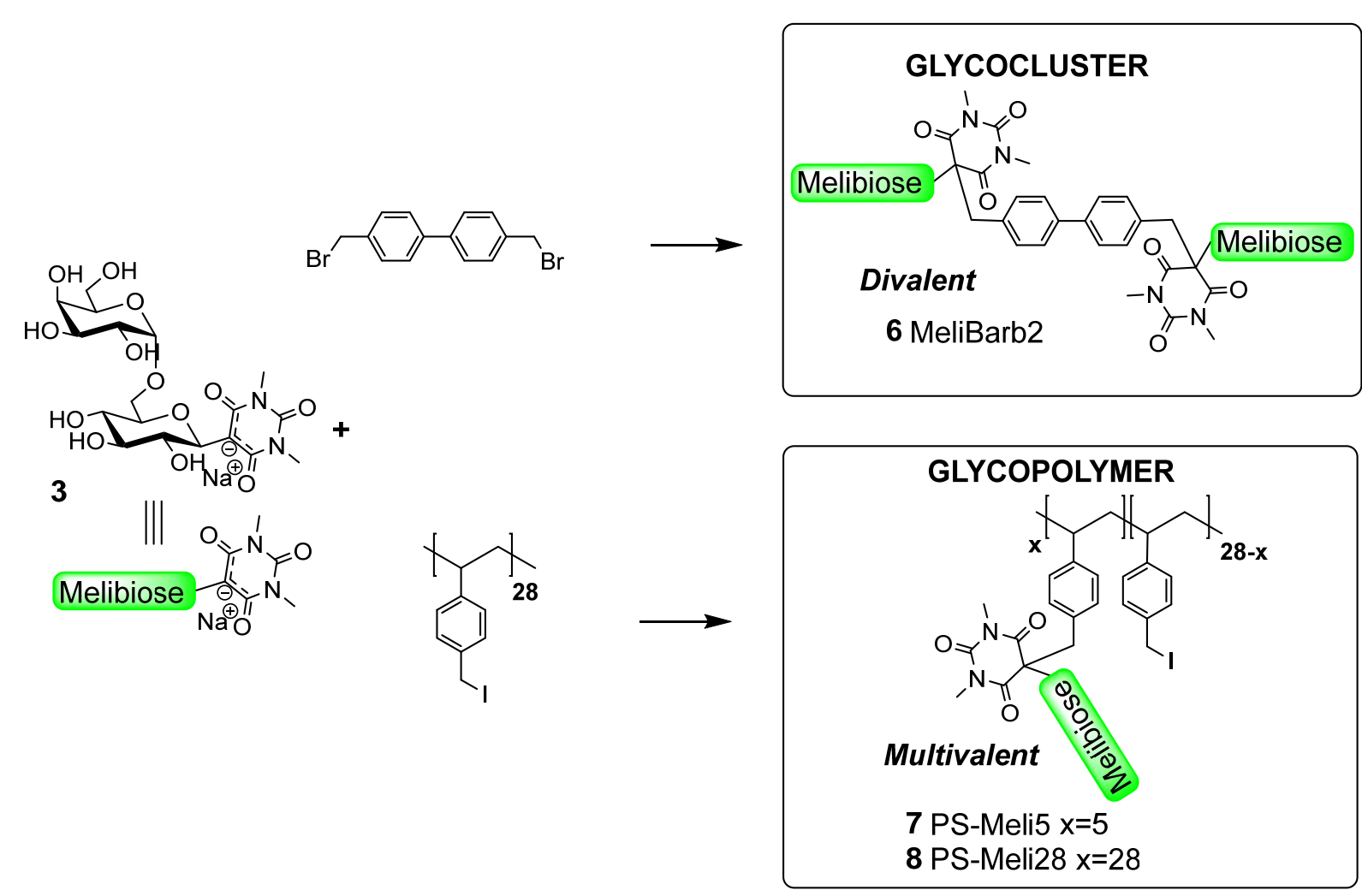

Scheme 2 Synthesis of melibiose-based glycocluster 6 and glycopolymers 7-8.

Divalent $C$-galactosylbarbiturate 6 (MeliBarb2) was prepared by coupling 1,3-dimethyl-( $\beta-C$ melibiosyl)barbituric acid sodium salt with 4,4'-bis(bromomethyl) $-1,1^{\prime}$-biphenyl in DMSO ... . This glycocluster was once again fully characterized by $1 \mathrm{D}$ and 2D NMR, IR spectroscopy and further confirmed by mass spectrometry.

The thermodynamic parameters determining the binding mode of the divalent ligand were investigated by ITC and compared to the monovalent reference MeliBarb 3 (Table 2). While the monovalent ligand 3 displayed a $K_{\mathrm{D}}$ value of $66.2 \mu \mathrm{M}$, the divalent one 6 showed a $K_{\mathrm{D}}$ value in the submicromolar range $\left(K_{\mathrm{D}}=0.41 \mu \mathrm{M}\right)$, resulting in a significant relative potency of 69 and highlighting the remarkable multivalent effect (Figure S57; SI). The stoichiometry (n) of 0.41 ((Table 2) for the complex 
generated between the lectin LecA and the glycocluster $\mathbf{6}$ indicates that all the carbohydrate epitopes are engaged. This result demonstrates that even if the molecular design of the linker has not been optimized, we were able to reach, in a rapid and convenient way, a potent lead glycocluster from a protecting-group free carbohydrate.

Similarly, the multivalent $C$-glycosylbarbiturate were generated from a polymer backbone bearing 4iodomethylstyrene, which have been substituted to append the $C$-melibiosylbarbiturate epitopes. The sodium salt $\mathbf{C}$-melibiosylbarbiturate $\mathbf{3}$ was conjugated along the polystyrene chain to afford a partial or full substitution that was controlled by the stoichiometry ratio. With 1 or 2 equivalents of 3 per 4 iodomethylstyrene monomer, the ${ }^{1} \mathrm{H}$ NMR spectrometry revealed $18 \%$ or $100 \%$ of substitution, respectively, which corresponded to 5 or 28 C-melibiosylbarbiturates per polymer chain (Figure S51; $\mathrm{SI})$.

The size of amphiphilic glycopolymers in water were first assessed by dynamic light scattering (DLS) and revealed hydrodynamic diameters of 290 and $16 \mathrm{~nm}$ for the partially substituted 7 that corresponds to micellar aggregates and $24 \mathrm{~nm}$ for the fully substituted 8 that fits with monodisperse micelles consisting of hydrophobic polystyrene as the micelle core and hydrophilic melibiose as the shell (Figure S52; SI).

Because of poor solubility of $\mathbf{7}$ in buffer and aggregation phenomena the binding affinity of the glycopolymers $\mathbf{7}$ and $\mathbf{8}$ to LecA was evaluated in a hemagglutination assay that measured the inhibition of LecA-induced agglutination of rabbit erythrocytes in comparison to melibiose used as the reference to calculate the relative potency (Table 3). (Figure S70; SI)

Table 3 Hemagglutination assay data for $P$. aeruginosa LecA binding with multivalent $\beta$ - $C$-melibiosyl barbiturate derivatives.

\begin{tabular}{llll}
\hline Ligand & $\boldsymbol{n}^{\mathbf{a}}$ & MIC $[\boldsymbol{\mu M}]^{\mathbf{b}}$ & r.p. $\mathbf{c} \boldsymbol{n}$ \\
\hline Melibiose & 1 & 3125 & 1 \\
7 PS-Meli5 & 5 & 44 & 14.2 \\
8 PS-Meli28 & 28 & 0.4 & 279 \\
$\mathbf{9}$ PS-Mal9 & 9 & - & - \\
\hline
\end{tabular}

${ }^{\mathrm{a}} n=$ Number of melibiose residues per ligand. ${ }^{\mathrm{b}} \mathrm{MIC}=$ minimal inhibitory concentration for the hemagglutination assay. The MIC corresponds to the highest dilution causing a complete inhibition of hemagglutination. ${ }^{\mathrm{c}}$ r.p. $/ n=$ relative potency per melibiose residue $=\left(\mathrm{MIC}_{\text {(melibiose) }} / \mathrm{MIC}_{\text {(ligand) }}\right) / n$.

The glycopolymer 7, with lower degree of substitution, exhibited a MIC of $44 \mu \mathrm{M}$ and was 14 -fold more potent than the monovalent melibiose reference highlighting the cluster effect. More interestingly, the fully substituted glycopolymer 8 led to strong inhibition with a MIC of $0.4 \mu \mathrm{M}$ resulting in a significant increase on valency-corrected relative potency (279). In combination with DLS data, this result indicates that increasing the saccharide density along the polystyrene backbone improves the binding towards LecA due to a better accessibility of ligand displayed at the surface of individual spherical micelles and led to a significant greater cluster effect. This result tendency is generally observed with amphiphilic glycopolymer nanoparticles..$^{30,31}$

\section{CONCLUSION}

In summary, we have demonstrated that Knoevenagel condensation using commercially available 1,3dimethyl barbituric acids and unprotected carbohydrates constitutes a rapid and versatile method for the scalable preparation of monovalent 1,3-dimethyl-( $\beta$ - $C$-glycopyranosyl)barbituric acid sodium salt useful for targeting diverse lectins (LecA, LecB and RSL) coming from opportunistic pathogens. An additional alkylation step allowed a versatile molecular design of monovalent carbohydrates but also 
the ease access to multivalent scaffolds from glycoclusters to glycopolymers. The $\beta-C$ glycosylbarbiturates-lectin recognition studies unraveled the impact of barbiturate ring which is unfavorable for binding $P$. aeruginosa lectins but to a lesser extent for RSL lectin allowing accommodation of hindered aglycon groups. The interactions were restored when oligosaccharides were used enabling distance of the recognition carbohydrate from the barbiturate ring. Thus, the synthetic strategy we have outlined for obtaining glycomimetics and their multivalent counterparts is one of the most efficient and rapid starting from protecting-group free carbohydrates. Obviously, various kind of non-hydrolyzable $\beta$ - $C$-glycosyl barbiturate systems could be obtained facilitating the development of glycosciences. In that sense, application of this methodology to attach carbohydrates to other materials are ongoing.

\section{EXPERIMENTAL PROCEDURES}

\section{General information}

All chemicals were obtained from Sigma-Aldrich (Saint Quentin Fallavier, France) or Carbosynth (Berkshire, United Kingdom), and were used as received. The poly(4-iodomethylstyrene) ( $M_{\mathrm{w}} 6830 \mathrm{~g}$ $\mathrm{mol}^{-1}, M_{\mathrm{w}} / M_{\mathrm{n}}=2.2$ ) was obtained from Specific Polymers (Castries, France). $\alpha$-L-fucopyranosyl-( $\left.1 \rightarrow 2\right)$ lactose was kindly offered by Dr. Eric Samain (CERMAV, Grenoble, France) who developed a biotechnological process to produce oligosaccharides. ${ }^{32}$ For carbohydrates, the progress of the reactions was monitored by thin layer chromatography using silica gel 60 F254 precoated plates (Merck). Spots were visualized using UV light and by charring with $3 \% \mathrm{H}_{2} \mathrm{SO}_{4}$ in $\mathrm{MeOH}$-water $(1: 1, \mathrm{v} / \mathrm{v})$. Silica gel 60 (Geduran ${ }^{\circledR}$ Si 60, 40-63 $\mu \mathrm{m}$, Merck) was used for column chromatography. IR spectra were recorded using a PerkinElmer spectrometer. The samples were analyzed by transmission from 400 to $4000 \mathrm{~cm}^{-1}$ (4 scans resolution 2). ${ }^{1} \mathrm{H}$ and ${ }^{13} \mathrm{C}$ NMR spectra were recorded at $298 \mathrm{~K}$ in appropriate deuterated solvents using Bruker Avance DRX400 (400 MHz) spectrometer and chemical shifts $(\delta)$ were reported in parts per million (ppm). Spectra were referenced to the residual proton solvent peaks relative to the signal of $\mathrm{D}_{2} \mathrm{O}\left(4.79 \mathrm{ppm}\right.$ for $\left.{ }^{1} \mathrm{H}\right)$ and $\mathrm{MeOH}-\mathrm{d}_{4}\left(\delta 3.31\right.$ and $49 \mathrm{ppm}$ for ${ }^{1} \mathrm{H}$ and ${ }^{13} \mathrm{C}$, respectively). Assignments were done by using 1D and 2D NMR correlations COSY and HSQC experiments. Mass spectra (ESI-MS) were recorded using on an Esquire 3000 spectrometer from Bruker. High-resolution mass spectra (HRMS-ESI) were performed on a Waters Xevo ${ }^{\circledR}$ G2-S QTof. Dynamic light scattering experiments were carried out at $25^{\circ} \mathrm{C}$ using an ALV laser goniometer, which consists of a $22 \mathrm{~mW}$ HeNe linearly polarized laser operating at a wavelength of $632.8 \mathrm{~nm}$ and an ALV5000/EPP multiple $\tau$ digital correlator with $125 \mathrm{~ns}$ initial sampling time. Isothermal titration calorimetry (ITC) was performed with a ITC200 Microcalorimeter from Malvern and the data was analyzed using the Microcal Origin software. At least two independent titrations were run. Molecular modeling ???. Hemagglutination inhibition assays were performed on rabbit erythrocytes (details in SI) with glycopolymers.

Synthesis of sodium 5-( $\beta$-D-galactopyranosyl)-1,3-dimethylbarbiturate (1). Sodium 5-( $\beta$-Dgalactopyranosyl)-1,3-dimethylbarbiturate synthesis is adapted from a procedure described by Gonzalez et al.. ${ }^{15} \mathrm{D}$-galactose $(5.54 \mathrm{mmol})$ and 1,3-dimethylbarbituric acid $(6.40 \mathrm{mmol})$ were dissolved in deionized water $(12.5 \mathrm{~mL})$ followed by the slow addition of $\mathrm{NaHCO} 3(6.30 \mathrm{mmol})$ in order to neutralize the $\mathrm{pH}$ at 6.5 . The mixture was then heated at $80^{\circ} \mathrm{C}$ and monitored by TLC (EtOAc/MeOH/H2O, 40/15/3, v/v). After 5h, D-galactose had been totally consumed and the reaction was stopped. Water was evaporated under reduced pressure and the obtained orange solid was redissolved into $\mathrm{MeOH}(25 \mathrm{~mL}$ ) using sonication. Thus, 1 was precipitated by adding $25 \mathrm{~mL}$ of EtOAc and the white solid was removed by filtration and washed two times with EtOAc and once with a EtOAc/MeOH (1/1) mixture. Finally, 1 was dried under reduced pressure at $60^{\circ} \mathrm{C}$ and obtained as a white powder (94\% yield). ${ }^{1} \mathrm{H}$ NMR $\left(400 \mathrm{MHz}, \mathrm{D}_{2} \mathrm{O}, 298 \mathrm{~K}\right) \delta 3.24\left(6 \mathrm{H}, \mathrm{s}, \mathrm{N}-\mathrm{CH}_{3}\right), 3.65(1 \mathrm{H}, \mathrm{dd}, J 3.5 \mathrm{~Hz}$, 
9.5 Hz, 3-H Gal), 3.70-3.78 (3H, m, 5-H Gal, 6-HH' Gal), 3.98 (1H, d, J 3.4 Hz, 4-H Gal), 4.48 (1H, d, J 10.0

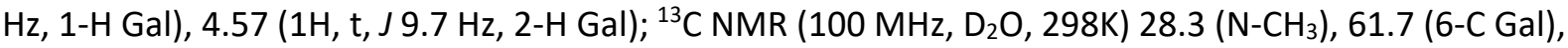
68.1 (2-C Gal), 70.4 (4-C Gal), 75.8 (3-C Gal), 77.2 (1-C Gal), 79.4 (5-C Gal), 86.9 (5-C barbiturate), 155.0 (2-C barbiturate); HRMS (ESI) m/z 341.0960 ([MNa + H] $]^{+}, \mathrm{C} 12 \mathrm{H} 18 \mathrm{~N} 2 \mathrm{O} 8 \mathrm{Na}$ calc. 341.0955).

Synthesis of 5-( $\beta$-D-galactopyranosyl)-1,3,5-trimethylbarbiturate (1a). 1 (1,47 mmol) was partially dissolved in DMSO $(2.0 \mathrm{~mL})$ and iodomethane $(2.94 \mathrm{mmol})$ was added. The reaction mixture was then stirred at room temperature for $24 \mathrm{~h}$ and monitored by TLC (DCM/MeOH, $8 / 2, \mathrm{v} / \mathrm{v})$ till complete conversion was achieved. DMSO was removed from the mixture using a Reveleris C18 40g pre-packed column eluted with gradient elution of methanol in water (0-100\%). Fractions that contained glycosylated products were collected and adsorbed on silica by evaporation. The silica powder was then placed on a column of silica packed with DCM and was eluted with DCM containing an increasing concentration of methanol (0-20\%). Evaporation under reduced pressure of the fractions that contained 1a gave a yellowish solid (70\% yield). ${ }^{1} \mathrm{H}$ NMR (400 MHz, MeOD, 298K) $\delta 1.63$ (3H, s, 5-CBarb$\left.\mathrm{CH}_{3}\right), 3.25\left(6 \mathrm{H}, \mathrm{d}, J 9.6 \mathrm{~Hz}, \mathrm{~N}-\mathrm{CH}_{3}\right), 3.37-3.42(2 \mathrm{H}, \mathrm{m}, 3-\mathrm{H} \mathrm{Gal}, 5-\mathrm{H}$ Gal), 3.60-3,69 (3H, m, 1-H Gal, 2-H Gal, 6-HH' Gal), 3.81 (1H, d, J $3.1 \mathrm{~Hz}, 4-\mathrm{H} \mathrm{Gal}) ;{ }^{13} \mathrm{C}$ NMR (100 MHz, MeOD, 298K) $\delta 20.6$ (5-CBarb- $\mathrm{CH}_{3}$ ), $28.8\left(\mathrm{~N}^{-\mathrm{CH}_{3}}\right.$ ), 29.0 ( $\mathrm{N}-\mathrm{CH}_{3}$ ), 62.5 (6-C Gal), 64.3 (5-C barbiturate), 70.3 (2-C Gal), 70.5 (4-C Gal), 76.8 (3C Gal), 80.9 (5-C Gal), 85.4 (1-C Gal), 153.0 (2-C barbiturate), 172.2-173.2 (4-C barbiturate, 6-C barbiturate); HRMS (ESI) $m / z 333.1296\left([\mathrm{M}+\mathrm{H}]^{+}, \mathrm{C}_{13} \mathrm{H}_{21} \mathrm{~N}_{2} \mathrm{O}_{8}\right.$ calc. 333.1298).

Synthesis of 5-( $\beta$-D-galactopyranosyl)-5-benzyl-1,3-dimethylbarbiturate (1b). 5-( $\beta$-Dgalactopyranosyl)-5-benzyl-1,3-dimethylbarbiturate synthesis is adapted from a procedure described by Wulff et al.. ${ }^{17} 1$ (1.47 mmol) was partially dissolved in DMSO $(15 \mathrm{~mL})$ and benzylbromide (2.94 $\mathrm{mmol}$ ) was added. The mixture was then stirred at room temperature for $24 \mathrm{~h}$ and monitored by TLC $(\mathrm{DCM} / \mathrm{MeOH}, 8 / 2, \mathrm{v} / \mathrm{v})$ till complete conversion was achieved. The reaction mixture was then precipitated into $50 \mathrm{~mL}$ of toluene and the obtained glue was sonicated in order to release entrapped DMSO. The solution was then filtered to retain the solid part. This process was repeated twice on the remaining glue stuck to the round flask and finally, all the solid parts were collected and dissolved in DCM. TLC showed that majority of DMSO was removed during the washing process. The solution was then placed on a column of silica packed with DCM and was eluted with DCM containing an increasing concentration of $\mathrm{MeOH}(0-20 \%)$. Evaporation under reduced pressure of the collected fractions gave 1b a white powder (90\% yield). ${ }^{1} \mathrm{H}$ NMR (400 MHz, MeOD, 298K) $\delta 3.03\left(3 \mathrm{H}, \mathrm{s}, \mathrm{N}-\mathrm{CH}_{3}\right), 3.09(3 \mathrm{H}, \mathrm{s}, \mathrm{N}-$ $\left.\mathrm{CH}_{3}\right)$, 3.42-3.49 (2H, m, 3-H Gal, CH- $\left.\phi\right), 3.51\left(1 \mathrm{H}, \mathrm{t}, J 5.7 \mathrm{~Hz}, 5-\mathrm{H}\right.$ Gal), $3.57\left(1 \mathrm{H}, \mathrm{d}, J 13.1 \mathrm{~Hz}, \mathrm{CH}^{\prime}-\phi\right)$, 3.71-3.80 (3H, m, 2-H Gal, 6-HH' Gal), 3.88 (1H, d, J 3.2 Hz, 4-H Gal), 3.99 (1H, d, J 9.8 Hz, 1-H Gal), 6.96-

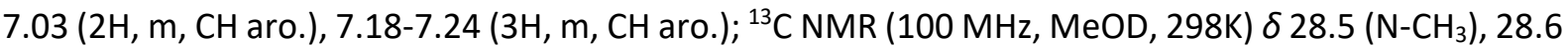
$\left(\mathrm{N}-\mathrm{CH}_{3}\right.$ ), $42.8\left(\mathrm{CH}_{2}-\phi\right), 61.7$ (5-C barbiturate), 62.7 (6-C Gal), 70.4 (2-C Gal), 71.0 (4-C Gal), 76.8 (3-C Gal), 81.5 (5-C Gal), 84.9 (1-C Gal), 128.6 (CH aro.), 129.5 (CH aro.), 130.5 (CH aro.), 136.4 (C aro. quat.), 151.9 (2-C barbiturate), 171.3-172.2 (4-C barbiturate, 6-C barbiturate); HRMS (ESI) $\mathrm{m} / z$ 409.1612 ([M $+\mathrm{H}]^{+}, \mathrm{C}_{19} \mathrm{H}_{25} \mathrm{~N}_{2} \mathrm{O}_{8}$ calc. 409.1605).

Synthesis of sodium 5-( $\beta$-D-melibiosyl)-1,3-dimethylbarbiturate (3). Sodium 5-( $\beta$-D-melibiosyl)-1,3dimethylbarbiturate dimethylbarbiturate synthesis is adapted from a procedure described by Critchley et al.. ${ }^{16}$ Melibiose monohydrate $(2.78 \mathrm{mmol})$ and 1,3-dimethylbarbituric acid $(3.19 \mathrm{mmol})$ were dissolved in deionized water $(6.5 \mathrm{~mL})$ followed by the slow addition of $\mathrm{NaHCO}_{3}(3.15 \mathrm{mmol})$ up to reach a $\mathrm{pH}$ of approximatively 6.5 . The mixture was then heated at $80^{\circ} \mathrm{C}$ and monitored by TLC (Acetonitrile/ $\mathrm{H}_{2} \mathrm{O}, 7.5 / 2.5, \mathrm{v} / \mathrm{v}$ ). After $6 \mathrm{~h}$, melibiose had been totally consumed and the reaction was stopped. Water was partially evaporated under reduced pressure, mixed with silica and dried. The silica powder was then placed on a column of silica packed with acetonitrile and was eluted with acetonitrile containing an increasing concentration of water (5-30\%). All the fractions that contains the 
product were then lyophilized to obtain an orange powder. To improve the purity, the solid was solubilized into $30 \mathrm{~mL}$ of $\mathrm{MeOH}$ heated under reflux and, after cooling at room temperature, $\mathbf{3}$ was precipitated by the addition of $60 \mathrm{~mL}$ of EtOAc. The white precipitate was removed by filtration and washed two times with EtOAc. Finally, 3 was dried under reduced pressure at $60^{\circ} \mathrm{C}$ and obtained as a white powder (89\% yield). ${ }^{1} \mathrm{H}$ NMR $\left(400 \mathrm{MHz}, \mathrm{D}_{2} \mathrm{O}, 298 \mathrm{~K}\right) \delta 3.23\left(6 \mathrm{H}, \mathrm{s}, \mathrm{N}-\mathrm{CH}_{3}\right), 3.49(1 \mathrm{H}, \mathrm{m}, 3-\mathrm{H} \mathrm{Glu})$, $3.61\left(1 \mathrm{H}, \mathrm{s}, 5^{\prime}-\mathrm{H} \mathrm{Gal}\right), 3.61(1 \mathrm{H}, \mathrm{d}, J 5.6 \mathrm{~Hz}, 4-\mathrm{H} \mathrm{Glu}), 3.71-3.74\left(3 \mathrm{H}, \mathrm{m}, 6-\mathrm{H} \mathrm{Glu}, 6^{\prime}-\mathrm{HH}^{\prime} \mathrm{Gal}\right), 3.80$ (1H, dd, J $3.8 \mathrm{~Hz}, 10.3 \mathrm{~Hz}, 2^{\prime}-\mathrm{H}$ Gal), 3.90 (1H, dd, J $3.3 \mathrm{~Hz}, 10.3 \mathrm{~Hz}, 3^{\prime}-\mathrm{H}$ Gal), 3.97-4.01 (3H, m, 5-H Glu, 6$\mathrm{H}^{\prime} \mathrm{Glu}, 4^{\prime}-\mathrm{H}$ Gal), $4.43(1 \mathrm{H}, \mathrm{t}, J 9.5 \mathrm{~Hz}, 2-\mathrm{H} \mathrm{Glu}), 4.53(1 \mathrm{H}, \mathrm{d}, J 10.0 \mathrm{~Hz}, 1-\mathrm{H} \mathrm{Glu}) ;{ }^{13} \mathrm{C} \mathrm{NMR}\left(100 \mathrm{MHz}, \mathrm{D}_{2} \mathrm{O}\right.$,

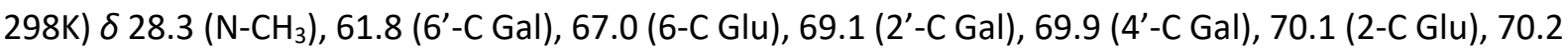
(3'-C Gal), 70.5 (4-C Glu), 71.5 (5-C Glu), 77.1 (1-C Glu), 78.9 (5'-C Gal), 79.2 (3-C Glu), 86.7 (5-C barbiturate), 98.9 (1'-C Gal), 155.1 (2-C barbiturate); HRMS (ESI) $m / z 503.1503$ ([MNa + H] , $\mathrm{C}_{18} \mathrm{H}_{28} \mathrm{~N}_{2} \mathrm{O}_{13} \mathrm{Na}$ calc. 503.1489).

Synthesis of sodium 5-( $\beta$-L-fucopyranosyl)-1,3-dimethylbarbiturate (2). L-Fucose $(12.2 \mathrm{mmol})$ and 1,3-dimethylbarbituric acid (14.1 mmol) were dissolved in deionized water $(27 \mathrm{~mL})$ followed by the slow addition of $\mathrm{NaHCO}_{3}(14.6 \mathrm{mmol})$ up to reach a $\mathrm{pH}$ of 6.5 . The mixture was then heated at $80^{\circ} \mathrm{C}$ and monitored by TLC $\left(\mathrm{ACN} / \mathrm{H}_{2} \mathrm{O}, 9 / 1, \mathrm{v} / \mathrm{v}\right)$. After $5 \mathrm{~h}$, L-fucose had been totally consumed and the reaction was stopped. Water was then totally evaporated under reduced pressure and the obtained orange solid was dissolved into $\mathrm{MeOH}(15 \mathrm{~mL}$ ) using sonication. Thus, 2 was precipitated by adding 45 $\mathrm{mL}$ of EtOAc, followed by a dispersion of the precipitate using sonication. The white solid was removed by filtration and washed two times with EtOAc. Finally, 2 was dried under reduced pressure at $60^{\circ} \mathrm{C}$ and obtained as a white powder (83\% yield). ${ }^{1} \mathrm{H}$ NMR ( $\left.400 \mathrm{MHz}, \mathrm{D}_{2} \mathrm{O}, 298 \mathrm{~K}\right) \delta 1.22(3 \mathrm{H}, \mathrm{d}, J 6.5 \mathrm{~Hz}, 6-$ $\mathrm{CH}_{3}$ Fuc), $3.23\left(6 \mathrm{H}, \mathrm{s}, \mathrm{N}-\mathrm{CH}_{3}\right), 3.64(1 \mathrm{H}, \mathrm{ddd}, J 8.0 \mathrm{~Hz}, J 3.7 \mathrm{~Hz}, J 1.3 \mathrm{~Hz}, 3-\mathrm{H}$ Fuc), $3.78(1 \mathrm{H}, \mathrm{dd}, J 3.5 \mathrm{~Hz}$, J $0.8 \mathrm{~Hz}, 4-\mathrm{H}$ Fuc), 3.83 (1H, qd, J $6.5 \mathrm{~Hz}, J 0.9 \mathrm{~Hz}, 5-\mathrm{H} \mathrm{Gal}), 4.46$ (1H, d, J $9.8 \mathrm{~Hz}, 1-\mathrm{H}$ Fuc), 4.48 (1H, q, J $9.2 \mathrm{~Hz}, 2-\mathrm{H}$ Fuc); ${ }^{13} \mathrm{C}$ NMR (100 MHz, $\left.\mathrm{D}_{2} \mathrm{O}, 298 \mathrm{~K}\right) \delta 16.5$ (6- $\mathrm{CH}_{3}$ Fuc), $28.3\left(\mathrm{~N}-\mathrm{CH}_{3}\right), 67.8$ (2-C Fuc), 73.3 (4-C Fuc), 75.2 (5-C Fuc), 75.9 (3-C Fuc), 76.9 (1-C Gal), 87.0 (5-C barbiturate), 155.0 (2-C barbiturate); HRMS (ESI) $m / z 325.1009$ ([MNa + H] $]^{+}, \mathrm{C}_{12} \mathrm{H}_{18} \mathrm{~N}_{2} \mathrm{O}_{7} \mathrm{Na}$ calc. 325.1006).

Synthesis of 5-( $\beta$-L-fucopyranosyl)-1,3,5-trimethylbarbiturate (2a). 2 (0.77 mmol) was partially dissolved in DMSO $(1.0 \mathrm{~mL})$ and iodomethane $(1.54 \mathrm{mmol})$ was added. The reaction mixture was then stirred at room temperature for $24 \mathrm{~h}$ and monitored by TLC (DCM/MeOH, 9.5/0.5, v/v) till complete conversion was achieved. 2a was purified using a Reveleris C18 $(40 \mathrm{~g})$ pre-packed column eluted with gradient elution of methanol in water (0-100\%). Fractions that contained 2 a were collected and lyophilized to give a white solid (90\% yield). $2 \mathrm{a}$ is a very hygroscopic compound. ${ }^{1} \mathrm{H} \mathrm{NMR}(400 \mathrm{MHz}$, $\left.\mathrm{D}_{2} \mathrm{O}, 298 \mathrm{~K}\right) 1.14\left(3 \mathrm{H}, \mathrm{d}, \mathrm{J} 6.5 \mathrm{~Hz}, 6-\mathrm{CH}_{3} \mathrm{Fuc}\right), 1.61\left(3 \mathrm{H}, \mathrm{s}, 5-\mathrm{CBarb}-\mathrm{CH}_{3}\right), 3.24\left(6 \mathrm{H}, \mathrm{d}, \mathrm{J} 2.0 \mathrm{~Hz}, \mathrm{~N}-\mathrm{CH}_{3}\right), 3.38$ $(1 \mathrm{H}, \mathrm{dd}, J 8.9 \mathrm{~Hz}, J 3.4 \mathrm{~Hz}, 3-\mathrm{H}$ Fuc), $3.50(1 \mathrm{H}, \mathrm{qd}, J 6.5 \mathrm{~Hz}, J 1.0 \mathrm{~Hz}, 5-\mathrm{H} \mathrm{Fuc}), 3.56$ (1H, dd, J $3.4 \mathrm{~Hz}, J 1.0$ $\mathrm{Hz}$, 4-H Fuc), $3.58\left(1 \mathrm{H}, \mathrm{d}, J 9.5 \mathrm{~Hz}, 1-\mathrm{H}\right.$ Fuc), (1H, q, J $9.0 \mathrm{~Hz}, 2-\mathrm{H}$ Fuc); ${ }^{13} \mathrm{C}$ NMR $\left(100 \mathrm{MHz}, \mathrm{D}_{2} \mathrm{O}, 298 \mathrm{~K}\right) \delta$ 16.8 (6- $\mathrm{CH}_{3}$ Fuc), 20.4 (5-CBarb- $\mathrm{CH}_{3}$ ), 28.7-28.9 $\left(\mathrm{N}-\mathrm{CH}_{3}\right.$ ), 55.7 (5-C barbiturate), 70.0 (2-C Fuc), 73.0 (4C Fuc), 76.4 (5-C Fuc), 77.0 (3-C Fuc), 85.4 (1-C Fuc), 153.1 (2-C barbiturate), 172.2-173.4 (4-C barbiturate, 6-C barbiturate); HRMS (ESI) $m / z 317.1345$ ([M+H] $]^{+}, \mathrm{C}_{13} \mathrm{H}_{21} \mathrm{~N}_{2} \mathrm{O}_{7}$ calc. 317.1349).

Synthesis of 5-( $\beta$-L-fucopyranosyl)-5-benzyl-1,3-dimethylbarbiturate (2b). 2 (1.47 mmol) was partially dissolved in DMF $(1.5 \mathrm{~mL})$ and benzylbromide $(2.94 \mathrm{mmol})$ was added. The reaction mixture was then stirred at room temperature for $24 \mathrm{~h}$ and monitored by TLC $\left(\mathrm{ACN} / \mathrm{H}_{2} \mathrm{O}, 9 / 1, \mathrm{v} / \mathrm{v}\right)$ till complete conversion was achieved. The mixture was then dried under $\mathrm{N}_{2}$ flow. The resulting orange film was solubilized in $\mathrm{MeOH}$ and then adsorbed on silica. $\mathbf{2 b}$ was purified using a Reveleris silica $(40 \mu \mathrm{m}, 40 \mathrm{~g})$ pre-packed column eluted with gradient elution of methanol in DCM (0-100\%). Fractions that contained $\mathbf{2} \mathbf{b}$ were collected and lyophilized to give a white foam ( $88 \%$ yield). ${ }^{1} \mathrm{H} N M R\left(400 \mathrm{MHz}, \mathrm{D}_{2} \mathrm{O}\right.$, 298K) $\delta 1.21\left(3 \mathrm{H}, \mathrm{d}, J 6.5 \mathrm{~Hz}, 6-\mathrm{CH}_{3} \mathrm{Fuc}\right), 3.05\left(6 \mathrm{H}, \mathrm{d}, J 9.7 \mathrm{~Hz}, \mathrm{~N}-\mathrm{CH}_{3}\right), 3.43(1 \mathrm{H}, \mathrm{dd}, J 9.2 \mathrm{~Hz}, J 3.3 \mathrm{~Hz}, 3-$ 


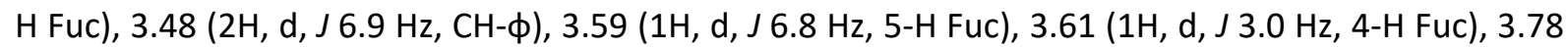
(1H, d, J $9.5 \mathrm{~Hz}, 2-\mathrm{H}$ Fuc), 3.93 (1H, d, J $9.6 \mathrm{~Hz}, 1-\mathrm{H} \mathrm{Fuc}), 6.99$ (2H, m, CH aro.), 7.20 (2H, m, CH aro.); ${ }^{13} \mathrm{C}$ NMR (100 MHz, $\left.\mathrm{D}_{2} \mathrm{O}, 298 \mathrm{~K}\right) \delta 16.9$ (6- $\left.\mathrm{CH}_{3} \mathrm{Fuc}\right), 28.4-28.6\left(\mathrm{~N}^{-\mathrm{CH}_{3}}\right), 42.5$ ( $\left.\mathrm{CH}_{2}-\phi\right), 62.1$ (5-C barbiturate), 70.1 (2-C Fuc), 73.3 (4-C Fuc), 77.0 (5-C Fuc), 77.1 (3-C Fuc), 84.1 (1-C Fuc), 128.6 (CH aro. para), 129.5 ( $\mathrm{CH}$ aro.), 130.5 ( $\mathrm{CH}$ aro.), 136.6 (C aro. quat.), 152.0 (2-C barbiturate), 171.4-172.1 (4-C barbiturate, 6-C barbiturate); HRMS (ESI) $m / z 415.1473\left([\mathrm{M}+\mathrm{Na}]^{+}, \mathrm{C}_{13} \mathrm{H}_{20} \mathrm{~N}_{2} \mathrm{O}_{7} \mathrm{Na}\right.$ calc. 415.1476).

Synthesis of sodium 5 -[ $\alpha$-L-fucopyranosyl)-(1 $\rightarrow 2)$ - $\beta$-D-lactosyl]-1,3-dimethylbarbiturate (4). $\alpha$-Lfucopyranosyl-(1 $\rightarrow 2)$-D-lactose $(0.61 \mathrm{mmol})$ and 1,3-dimethylbarbituric acid $(0.74 \mathrm{mmol})$ were dissolved in deionized water $(2 \mathrm{~mL})$ followed by the slow addition of $\mathrm{NaHCO}_{3}(68 \mathrm{mg})$ up to reach $\mathrm{pH}$ 6.5. The mixture was then heated at $80^{\circ} \mathrm{C}$ and monitored by TLC (Acetonitrile/ $\mathrm{H}_{2} \mathrm{O}, 7 / 3, \mathrm{v} / \mathrm{v}$ ). After $6 \mathrm{~h}$, $\alpha$-L-fucopyranosyl-( $(1 \rightarrow 2)$-D-lactose had been totally consumed and the reaction was stopped. Water was partially evaporated under reduced pressure and the concentrated mixture was then added, drop by drop, to $50 \mathrm{~mL}$ of $i-\mathrm{PrOH}$ in order to induce precipitation of 4 . The white precipitate was removed by filtration and washed three times with $5 \mathrm{~mL}$ of acetone. Finally, the precipitate was solubilized in water and freeze dried to give 4 as a white foam (67\% yield). ${ }^{1} \mathrm{H}$ NMR $\left(400 \mathrm{MHz}, \mathrm{D}_{2} \mathrm{O}, 298 \mathrm{~K}\right) \delta 1.31(3 \mathrm{H}$, d, J $\left.6.6 \mathrm{~Hz}, 6^{\prime \prime}-\mathrm{CH}_{3} \mathrm{Fuc}\right), 3.26\left(6 \mathrm{H}, \mathrm{N}-\mathrm{CH}_{3}\right), 3.54\left(1 \mathrm{H}, \mathrm{d}, J 8.4 \mathrm{~Hz}, 3^{\prime \prime}-\mathrm{H}\right.$ Fuc), $3.64(1 \mathrm{H}, \mathrm{t}, J 9.1 \mathrm{~Hz}, 3-\mathrm{H} \mathrm{Glu})$, 3.70-4.0 (10H, m, 4-H Glu, 5-H Glu, 6-HH' Glu, 3'-H Gal, 5'-H Gal, 6'-HH' Gal, 2"-H Fuc, 4"-Fuc), 3.78 (1H, s, 2'-H Gal), $3.95\left(1 \mathrm{H}, \mathrm{s}, 4^{\prime}-\mathrm{H} \mathrm{Gal}\right), 4.32\left(1 \mathrm{H}, \mathrm{q}, J 6.5 \mathrm{~Hz}, 5^{\prime \prime}-\mathrm{H} \mathrm{Fuc}\right), 4.47$ (1H, t, J 9.5 Hz, 2-H Glu), 4.58 $(1 \mathrm{H}, \mathrm{d}, J 9.9 \mathrm{~Hz}, 1-\mathrm{H} \mathrm{Glu}), 4.64\left(1 \mathrm{H}, \mathrm{d}, J 7.8 \mathrm{~Hz}, 1^{\prime}-\mathrm{H} \mathrm{Gal}\right), 5.37\left(1 \mathrm{H}, \mathrm{d}, J 5.1 \mathrm{~Hz}, 1^{\prime \prime}-\mathrm{H} \mathrm{Fuc}\right) ;{ }^{13} \mathrm{C}$ NMR (100 $\left.\mathrm{MHz}, \mathrm{D}_{2} \mathrm{O}, 298 \mathrm{~K}\right) \delta 15.3$ (6"- $\mathrm{CH}_{3} \mathrm{Fuc}$ ), 27.6 ( $\left(\mathrm{N}-\mathrm{CH}_{3}\right), 60.1$ (6-C Glu), 61.1 (6'-C Gal), 66.9 (5"-C Fuc), 68.2 (2"'-C Fuc), 69.2 (4'-C Gal), 69.3 (2-C Glu), 69.6 (5-C Glu), 71.7 (5'-C Gal), 73.6 (4-C Glu), 75.2 (2'-C Gal), 75.5 (4"-C Fuc), 76.0 (1-C Glu), 76.2 (3'-C Gal), 76.7 (3-C Glu), 78.9 (3"'-C Fuc), 85.9 (5-C barbiturate), 98.8 (1"'-C FuC), 100.2 (1'-C Gal), 154.3 (2-C barbiturate); HRMS (ESI) $\mathrm{m} / \mathrm{z} 649.2062$ ([M + H ] , $\mathrm{C}_{24} \mathrm{H}_{38} \mathrm{~N}_{2} \mathrm{O}_{17}$ calc. 649.2068).

Synthesis of sodium 5-( $\beta$-D-maltosyl)-1,3-dimethylbarbiturate (5). Sodium 5-( $\beta$-D-maltosyl)-1,3dimethylbarbiturate synthesis is adapted from a procedure described by Critchley et al.. ${ }^{16} \mathrm{D}$-Maltose monohydrate $(2.8 \mathrm{mmol})$ and 1,3-dimethylbarbituric acid $(3,32 \mathrm{mmol})$ were dissolved in deionized water $(6 \mathrm{~mL})$ followed by the slow addition of $\mathrm{NaHCO}_{3}(280 \mathrm{mg})$ up to $\mathrm{pH}$ 6.5. The mixture was then heated at $80^{\circ} \mathrm{C}$ and monitored by TLC (Acetonitrile/ $\mathrm{H}_{2} \mathrm{O}, 8 / 2, \mathrm{v} / \mathrm{v}$ ) till complete conversion was achieved. 5 was purified using a Reveleris $\mathrm{C} 1840 \mathrm{~g}$ pre-packed column eluted with gradient elution of methanol in water (0-20\%). Fractions that contained $\mathbf{5}$ were collected and freeze-dried to give a yellowish solid ( $99 \%$ yield). 5 could be also purified by precipitation. After complete conversation of Dmaltose, water was partially evaporated under reduce pressure and the concentrated mixture was then added, drop by drop, to $100 \mathrm{~mL}$ of $i-\mathrm{PrOH}$ in order to induce precipitation of $\mathbf{5}$. The white precipitate was removed by filtration and washed three times with $10 \mathrm{~mL}$ of acetone. Finally, 5 was dried under reduced pressure at $60^{\circ} \mathrm{C}$ and obtained as a white powder (93\% yield). ${ }^{1} \mathrm{H} \mathrm{NMR} \mathrm{(400} \mathrm{MHz}$, $\left.\mathrm{D}_{2} \mathrm{O}, 298 \mathrm{~K}\right) \delta 3.23\left(6 \mathrm{H}, \mathrm{s}, \mathrm{N}-\mathrm{CH}_{3}\right), 3.44\left(1 \mathrm{H}, \mathrm{t}, J 9.2 \mathrm{~Hz}, 4^{\prime}-\mathrm{H} \mathrm{Glu}\right), 3.57-3.62\left(2 \mathrm{H}, \mathrm{m}, 2^{\prime}-\mathrm{H}\right.$ Glu, 4-H Glu), $3.73\left(1 \mathrm{H}, \mathrm{t}, J 9.5 \mathrm{~Hz}, 3^{\prime}-\mathrm{H} \mathrm{Glu}\right), 3.77-3.88$ (7H, m, 3-H Glu, 5-H Glu, 6-HH' Glu, 5'-H Glu, 6'-HH' Glu), 4.40 $(1 \mathrm{H}, \mathrm{t}, J 9.4 \mathrm{~Hz}, 2-\mathrm{H} \mathrm{Glu}), 4.55(1 \mathrm{H}, \mathrm{d}, J 9.9 \mathrm{~Hz}, 1-\mathrm{H} \mathrm{Glu}), 5.45\left(1 \mathrm{H}, \mathrm{d}, J 3.9 \mathrm{~Hz}, 1^{\prime}-\mathrm{H} \mathrm{Glu}\right) ;{ }^{13} \mathrm{C}$ NMR $(100$ $\left.\mathrm{MHz}, \mathrm{D}_{2} \mathrm{O}, 298 \mathrm{~K}\right) \delta 28.4$ ( $\left.\mathrm{N}-\mathrm{CH}_{3}\right), 61.2$ (6'-C Glu), 61.5 (6-C Glu), 70.1 (2-C Glu, 4'-C Glu), 72.6 (2'-C Glu), 73.4 (3-C Glu), 73.7 (3'-C Glu), 76.7 (1-C Glu), 77.8 (5-C Glu), 79.0 (4-C Glu), 79.4 (5'-C Glu), 86.8 (5-C barbiturate), 100.6 (1'-C Glu), 155.1 (2-C barbiturate); HRMS (ESI) $\mathrm{m} / \mathrm{z} 503.1498$ ([MNa $+\mathrm{H}]^{+}$, $\mathrm{C}_{18} \mathrm{H}_{28} \mathrm{~N}_{2} \mathrm{O}_{13} \mathrm{Na}$ calc. 503.1489).

Synthesis of $\alpha, \alpha^{\prime}$-Di[3",5"-dimethyl-1"-( $\beta$-D-melibiosyl)pyrimidine-2",4",6"-trione]-p,p'-bitolyl (6). 3 $(0.4 \mathrm{mmol})$ was partially dissolved in dry DMSO $(1.5 \mathrm{~mL})$ and 4,4'-(bisbromométhyl)biphenyl $(0.07$ $\mathrm{mmol})$ was added. The mixture was then stirred at $70^{\circ} \mathrm{C}$ for $5 \mathrm{~h}$ and monitored by TLC $\left(\mathrm{ACN} / \mathrm{H}_{2} \mathrm{O}, 8 / 2\right.$, 
v/v). 3 was not totally converted. 6 was purified from the mixture using a Reveleris C18 40g pre-packed column eluted with gradient elution of methanol in water (0-100\%). Evaporation under reduced pressure of the fractions that contained 6 gave a syrup which was diluted in water and freeze dried to obtain a white foam (72\% yield). ${ }^{1} \mathrm{H}$ NMR $(400 \mathrm{MHz}, \mathrm{MeOD}, 298 \mathrm{~K}) \delta 3.09\left(12 \mathrm{H}, \mathrm{d}, J 5.7 \mathrm{~Hz}, \mathrm{~N}-\mathrm{CH}_{3}\right), 3.24$ ( $2 \mathrm{H}, \mathrm{t}, J 9.3 \mathrm{~Hz}, 4-\mathrm{H} \mathrm{Glu}), 3.34(2 \mathrm{H}, \mathrm{t}, J 8.8 \mathrm{~Hz}, 3-\mathrm{H} \mathrm{Glu}), 3.47(2 \mathrm{H}, \mathrm{m}, 5-\mathrm{H} \mathrm{Glu}), 3.51$ (2H, s, 6'-H Gal), 3.54 (2H, s, 6'-H' Gal), 3.56-3.88 (18H, m, $\underline{\mathrm{CH}}_{2}-\phi, 2-\mathrm{H} \mathrm{Glu}, 6-\mathrm{HH}^{\prime} \mathrm{Glu}, 2^{\prime}-\mathrm{H}$ Gal, 3'-H Gal, 4'-H Gal, 5'-H Gal), $4.05(2 \mathrm{H}, \mathrm{d}, J 9.8 \mathrm{~Hz}, 1-\mathrm{H} \mathrm{Glu}), 4.9\left(2 \mathrm{H}, 1^{\prime}-\mathrm{H}\right.$ Gal), 7.05 (4H, d, J $8.2 \mathrm{~Hz}, \mathrm{CH}$ aro.), $7.44(4 \mathrm{H}, \mathrm{d}, J 8.3 \mathrm{~Hz}, \mathrm{CH}$

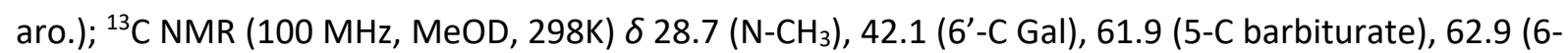
C Glu), 68.0 ( $\left.\mathrm{CH}_{2}-\phi\right), 70.4$ (2'-C Gal), 71.2 (5'-C Gal), 71.5 (3'-C Gal), 71.7 (4-C Glu), 72.4 (4'-C Gal), 72.9 (2-C Glu), 80.1 (3-C Glu), 81.1 (5-C Glu), 84.2 (1-C Glu), 100.2 (1'-C Gal), 127.8 (CH aro.), 131.1 (C aro. quat.), 135.6 (C aro. quat.), 152.0 (2-C barbiturate), 171.3-172.1 (4-C barbiturate, 6-C barbiturate); HRMS (ESI) $m / z 1161.3844\left([\mathrm{M}+\mathrm{Na}]^{+}, \mathrm{C}_{13} \mathrm{H}_{20} \mathrm{~N}_{2} \mathrm{O} 7 \mathrm{Na}\right.$ calc. 1161.3857).

General procedure for the synthesis of meliobiose or maltose bearing glycopolymers (7), (8) \& (9). ???

\section{ASSOCIATED CONTENT}

\section{Supporting Information}

The supporting information is available free of charge on the ACS Publications website... .

NMR \& FT-IR spectra of $\beta$-C-glycosylbarbiturates. Raw ITC data and pictures of hemagglutination assays.

\section{AUTHOR INFORMATION}

\section{Corresponding Author}

*E-mail: sami.halila@cermav.cnrs.fr

\section{ORCID}

François Portier: ???

Anne Imberty: 0000-0001-6825-9527

Sami Halila: 0000-0002-9673-1099

\section{Notes}

The authors declare no competing financial interest.

\section{ACKNOWLEDGEMENTS}

This work was supported by CNRS, Universite Grenoble Alpes, the Labex ARCANE (ANR-11-LABX0003-01) and the Glyco@Alps project ANR-15-IDEX-02). We thank Emilie Gillon for her help in ITC measurements and ICMG FR 2607 platform (NMR, mass spectrometry) for the structural analyses.

\section{REFERENCES}

(1) Varki, A. Biological Roles of Glycans. Glycobiology 2017, 27 (1), 3-49. https://doi.org/10.1093/glycob/cww086.

(2) Bernardi, A.; Jiménez-Barbero, J.; Casnati, A.; De Castro, C.; Darbre, T.; Fieschi, F.; Finne, J.; Funken, H.; Jaeger, K.-E.; Lahmann, M.; et al. Multivalent Glycoconjugates as Anti-Pathogenic Agents. Chem. Soc. Rev. 2013, 42 (11), 4709-4727. https://doi.org/10.1039/C2CS35408J. 
(3) Poole, J.; Day, C. J.; von Itzstein, M.; Paton, J. C.; Jennings, M. P. Glycointeractions in Bacterial Pathogenesis. Nature Reviews Microbiology 2018, 16 (7), 440-452.

https://doi.org/10.1038/s41579-018-0007-2.

(4) Villadsen, K.; Martos-Maldonado, M. C.; Jensen, K. J.; Thygesen, M. B. Chemoselective Reactions for the Synthesis of Glycoconjugates from Unprotected Carbohydrates.

ChemBioChem 2017, 18 (7), 574-612. https://doi.org/10.1002/cbic.201600582.

(5) Hjuler, C. T.; Maolanon, N. N.; Sauer, J.; Stougaard, J.; Thygesen, M. B.; Jensen, K. J.

Preparation of Glycoconjugates from Unprotected Carbohydrates for Protein-Binding Studies. Nature Protocols 2017, 12, 2411.

(6) Halila, S.; Manguian, M.; Fort, S.; Cottaz, S.; Hamaide, T.; Fleury, E.; Driguez, H. Syntheses of Well-Defined Glyco-Polyorganosiloxanes by "Click" Chemistry and Their Surfactant Properties. Macromol. Chem. Phys. 2008, 209 (Copyright (C) 2018 American Chemical Society (ACS). All Rights Reserved.), 1282-1290. https://doi.org/10.1002/macp.200700629.

(7) Guerry, A.; Bernard, J.; Samain, E.; Fleury, E.; Cottaz, S.; Halila, S. Aniline-Catalyzed Reductive Amination as a Powerful Method for the Preparation of Reducing End-"Clickable" Chitooligosaccharides. Bioconjugate Chem. 2013, 24 (Copyright (C) 2018 American Chemical Society (ACS). All Rights Reserved.), 544-549. https://doi.org/10.1021/bc3003716.

(8) Cushen, J. D.; Otsuka, I.; Bates, C. M.; Halila, S.; Fort, S.; Rochas, C.; Easley, J. A.; Rausch, E. L.; Thio, A.; Borsali, R.; et al. Oligosaccharide/Silicon-Containing Block Copolymers with $5 \mathrm{Nm}$ Features for Lithographic Applications. ACS Nano 2012, 6 (Copyright (C) 2018 American Chemical Society (ACS). All Rights Reserved.), 3424-3433. https://doi.org/10.1021/nn300459r.

(9) Scherrmann, M.-C. Knoevenagel Reaction of Unprotected Sugars. In Carbohydrates in Sustainable Development II; Rauter, A. P., Vogel, P., Queneau, Y., Eds.; Springer Berlin Heidelberg: Berlin, Heidelberg, 2010; pp 1-18. https://doi.org/10.1007/128_2010_49.

(10) Yang, Y.; Yu, B. Recent Advances in the Chemical Synthesis of C-Glycosides. Chem. Rev. 2017, 117 (19), 12281-12356. https://doi.org/10.1021/acs.chemrev.7b00234.

(11) Lalitha, K.; Muthusamy, K.; Prasad, Y. S.; Vemula, P. K.; Nagarajan, S. Recent Developments in $\beta$-C-Glycosides: Synthesis and Applications. Carbohydrate Research 2015, 402, 158-171. https://doi.org/10.1016/j.carres.2014.10.008.

(12) Galbis Perez, J. A.; Avalos Gonzalez, M.; Jimenez Requejo, J. L.; Palacios Albarran, J. C. A Facile Synthesis of C-Glycosylbarbiturates. Carbohydrate Research 1983, 124 (1), C15-C17. https://doi.org/10.1016/0008-6215(83)88372-4.

(13) Rodrigues, F.; Canac, Y.; Lubineau, A. A Convenient, One-Step, Synthesis of $\beta$--Glycosidic Ketones in Aqueous Media. Chem. Commun. 2000, No. 20, 2049-2050. https://doi.org/10.1039/B006642G.

(14) Riemann, I.; Fessner, W.-D.; Papadopoulos, M. A.; Knorst, M. C-Glycosides by Aqueous Condensation of $\beta$-Dicarbonyl Compounds with Unprotected Sugars. Aust. J. Chem. 2002, 55 (2), 147-154.

(15) Gonzalez, M. A.; Jimenez Requejo, J. L.; Palacios Albarran, J. C.; Gabis Perez, J. A. Facile Preparation of C-Glycosylbarbiturates and C-Glycosylbarbituric Acids. Carbohydrate Research 1986, 158, 53-66. https://doi.org/10.1016/0008-6215(86)84005-8.

(16) Critchley, P.; Clarkson, G. J. Carbohydrate-Protein Interactions at Interfaces: Comparison of the Binding of Ricinus Communis Lectin to Two Series of Synthetic Glycolipids Using Surface Plasmon Resonance Studies. Org. Biomol. Chem. 2003, 1 (23), 4148-4159. https://doi.org/10.1039/B306784J.

(17) Wulff, G.; Clarkson, G. On the Synthesis of C-Glycosyl Compounds Containing Double Bonds without the Use of Protecting Groups. Carbohydrate Research 1994, 257 (1), 81-95. https://doi.org/10.1016/0008-6215(94)84109-8.

(18) Wulff, G.; Clarkson, G. New Type of Polyvinylsaccharides with N,N-Dimethylbarbituric Acid as a Linker between Sugar and Styrene Residue. Macromolecular Chemistry and Physics 1994, 195 (7), 2603-2610. https://doi.org/10.1002/macp.1994.021950728. 
(19) Chemani, C.; Imberty, A.; de Bentzmann, S.; Pierre, M.; Wimmerová, M.; Guery, B. P.; Faure, K. Role of LecA and LecB Lectins in <em>Pseudomonas Aeruginosa</Em>-Induced Lung Injury and Effect of Carbohydrate Ligands. Infect. Immun. 2009, 77 (5), 2065.

https://doi.org/10.1128/IAI.01204-08.

(20) Kostlánová, N.; Mitchell, E. P.; Lortat-Jacob, H.; Oscarson, S.; Lahmann, M.; Gilboa-Garber, N.; Chambat, G.; Wimmerová, M.; Imberty, A. The Fucose-Binding Lectin from Ralstonia Solanacearum: A NEW TYPE OF $\beta$-PROPELLER ARCHITECTURE FORMED BY OLIGOMERIZATION AND INTERACTING WITH FUCOSIDE, FUCOSYLLACTOSE, AND PLANT XYLOGLUCAN. Journal of Biological Chemistry 2005, 280 (30), 27839-27849. https://doi.org/10.1074/jbc.M505184200.

(21) Cecioni, S.; Imberty, A.; Vidal, S. Glycomimetics versus Multivalent Glycoconjugates for the Design of High Affinity Lectin Ligands. Chemical Reviews 2015, 115 (1), 525-561. https://doi.org/10.1021/cr500303t.

(22) Sommer, R.; Wagner, S.; Rox, K.; Varrot, A.; Hauck, D.; Wamhoff, E.-C.; Schreiber, J.; Ryckmans, T.; Brunner, T.; Rademacher, C.; et al. Glycomimetic, Orally Bioavailable LecB Inhibitors Block Biofilm Formation of Pseudomonas Aeruginosa. J. Am. Chem. Soc. 2018, 140 (7), 2537-2545. https://doi.org/10.1021/jacs.7b11133.

(23) Rodrigue, J.; Ganne, G.; Blanchard, B.; Saucier, C.; Giguère, D.; Shiao, T. C.; Varrot, A.; Imberty, A.; Roy, R. Aromatic Thioglycoside Inhibitors against the Virulence Factor LecA from Pseudomonas Aeruginosa. Organic \& Biomolecular Chemistry 2013, 11 (40), 6906. https://doi.org/10.1039/c3ob41422a.

(24) Blanchard, B.; Imberty, A.; Varrot, A. Secondary Sugar Binding Site Identified for LecA Lectin from Pseudomonas Aeruginosa. Proteins: Structure, Function, and Bioinformatics 2013, 82 (6), 1060-1065. https://doi.org/10.1002/prot.24430.

(25) Sabin, C.; Mitchell, E. P.; Pokorná, M.; Gautier, C.; Utille, J.-P.; Wimmerová, M.; Imberty, A. Binding of Different Monosaccharides by Lectin PA-IIL from Pseudomonas Aeruginosa: Thermodynamics Data Correlated with X-Ray Structures. FEBS Letters 2006, 580 (3), 982-987. https://doi.org/10.1016/j.febslet.2006.01.030.

(26) Millan, M.; Conde, C. F.; Márquez, R. Structure of 5- $\beta$-d-Galactopyranosyl-1,3Dimethylbarbituric Acid Monohydrate, $\mathrm{C} 12 \mathrm{H} 18 \mathrm{~N} 2 \mathrm{O}$. H2O. Acta Crystallographica Section C 1985, 41 (2), 274-277. https://doi.org/10.1107/S0108270185003602.

(27) Kadam, R. U.; Garg, D.; Schwartz, J.; Visini, R.; Sattler, M.; Stocker, A.; Darbre, T.; Reymond, J.L. CH- $\pi$ "T-Shape" Interaction with Histidine Explains Binding of Aromatic Galactosides to Pseudomonas Aeruginosa Lectin LecA. ACS Chem. Biol. 2013, 8 (9), 1925-1930. https://doi.org/10.1021/cb400303w.

(28) Richichi, B.; Imberty, A.; Gillon, E.; Bosco, R.; Sutkeviciute, I.; Fieschi, F.; Nativi, C. Synthesis of a Selective Inhibitor of a Fucose Binding Bacterial Lectin from Burkholderia Ambifaria. Organic \& Biomolecular Chemistry 2013, 11 (24), 4086. https://doi.org/10.1039/c3ob40520f.

(29) Dam, T. K.; Brewer, C. F. Thermodynamic Studies of Lectin-Carbohydrate Interactions by Isothermal Titration Calorimetry. Chem. Rev. 2002, 102 (2), 387-430. https://doi.org/10.1021/cr000401x.

(30) Chen, G.; Amajjahe, S.; Stenzel, M. H. Synthesis of Thiol-Linked Neoglycopolymers and Thermo-Responsive Glycomicelles as Potential Drug Carrier. Chem. Commun. 2009, No. 10, 1198-1200. https://doi.org/10.1039/B900215D.

(31) Bonduelle, C.; Oliveira, H.; Gauche, C.; Huang, J.; Heise, A.; Lecommandoux, S. Multivalent Effect of Glycopolypeptide Based Nanoparticles for Galectin Binding. Chem. Commun. 2016, 52 (75), 11251-11254. https://doi.org/10.1039/C6CC06437J.

(32) Drouillard, S.; Driguez, H.; Samain, E. Large-Scale Synthesis of H-Antigen Oligosaccharides by Expressing Helicobacter Pylori A1,2-Fucosyltransferase in Metabolically Engineered Escherichia Coli Cells. Angewandte Chemie International Edition 2006, 45 (11), 1778-1780. https://doi.org/10.1002/anie.200503427. 